\title{
AUNC
}

Zabytkoznawstwo i Konserwatorstwo XLIX

Toruń 2018

DOI: http://dx.doi.org/10.12775/AUNC_ZiK.2018.002

\section{Kościół farny pw. św. Marii Magdaleny w Poznaniu i jego wyposażenie w świetle rachunków $z$ lat 1612-1652}

\section{FRANCISZEK SKIBIŃSKI}

Zakład Historii Sztuki Średniowiecznej i Nowożytnej

Wydział Sztuk Pięknych, UMK w Toruniu

e-mail:franek_skibinski@umk.pl

ORCID: 0000-0002-5084-9745

Key words: Parish church, Poznan, Poland, 17th century, building industry, sculpture

Słowa kluczowe: Kościół Marii Magdaleny, Poznań, XVII w., budownictwo, rzeźba

\begin{abstract}
The Church of Mary Magdalene in Poznan and its furbishing in light of the pay-book of the church from the years 1612-1652

Through the centuries the church of Mary Magdalene in Poznań was the most important sacral building in the city. Because of its demolition at the turn of the 19th century it remains however a blind spot in art historical research. This article presents new evidence concerning the history of the building and its furbishing in the first half of the 17th century. It is based on the accounts found in the hitherto unpublished pay-book of the church from the years 1612-1652, which is supplemented with information derived from other sources. In that period the church was furbished with a monumental stone ciborium, which was partially made in Gdańsk (1627-1629), and an organ prospect built by the master Walenty Mniszek (1632-1637). In addition, the pay-book contains information on the building works carried out in the church which included repair of the tower and of the roofing. Particularly important is the new evidence concerning some of the leading artists in Poznan who worked in the church, such as the sculptor Christpher Redel, who oversaw the making of the ciborium, as
\end{abstract}


well as the sculptor Conrad Pot and the painters Jakub Stephan and Georg Langner, who decorated the organs.

\begin{abstract}
Abstrakt
Kościół parafialny pw. Marii Magdaleny był przez stulecia najważniejszą budowlą sakralną w Poznaniu. Jego rozbiórka na przełomie XVIII i XIX w. spowodowała jednak, że pozostaje on słabo rozpoznany pod względem historyczno-artystycznym. Niniejszy artykuł przedstawia nowe informacje na temat dziejów budowli i jej wyposażenia w 1 poł. XVII w. Punktem wyjścia są rachunki zawarte w niepublikowanej dotąd księdze rachunkowej kościoła z lat 1612-1652, uzupełnione o informacje pochodzące $\mathrm{z}$ innych źródeł. W tym czasie kościół otrzymał m.in. monumentalne kamienne cyborium, częściowo wykonane w Gdańsku (1627-1629), oraz prospekt organowy, wykonany przez mistrza Walentego Mniszka (1632-1637). Księga rachunkowa dostarcza również informacji na temat prac budowlanych prowadzonych w kościele, m.in. napraw wieży oraz dachu. Szczególnie istotne są zawarte w księdze informacje dotyczące kilku spośród najważniejszych poznańskich artystów tego czasu, w tym rzeźbiarzu Krzysztofie Redelu, który był odpowiedzialny za budowę wspomnianego cyborium, a także o rzeźbiarzu Konradzie Pocie i malarzach Jakubie Stephanie i Jerzym Langnerze, którzy pracowali przy budowie prospektu.
\end{abstract}

Wielkie kościoły farne należały do najważniejszych ośrodków kształtujących życie miejskich wspólnot dawnej Rzeczpospolitej. Ich mury stanowiły ramy ceremonii mających - poza oczywistym wymiarem kultowym - ogromne znaczenie dla spoistości tkanki społecznej. Chrzty, śluby i pogrzeby, będące ważnymi wydarzeniami w życiu jednostek, rodzin i całych społeczności, odbywały w kaplicach i w sąsiedztwie ołtarzy fundowanych i utrzymywanych przez członków najważniejszych rodów, bractw religijnych i cechów rzemieślniczych ${ }^{1}$. Jako nekropolie kościoły były też miejscami, w których wspólnota kultywowała pamięć o swoich zmarłych członkach i składała swe wspomnienia, przez co stawały się materialnym świadectwem jej trwania w czasie i przestrzeni ${ }^{2}$. Istotna rola kościołów sprawiała, że władze miejskie, bractwa i cechy rzemieślnicze, a także osoby prywatne łożyły duże sumy na ich utrzymanie, dostosowanie do bieżących potrzeb i jak najświetniejsze wyposażenie. W przedsięwzięcia te angażowani byli budowniczowie, artyści i rzemieślnicy

$1 \quad$ Patrz np. Edmund Kizik, Wesele, kilka chrztów i pogrzebów. Uroczystości rodzinne w mieście hanzeatyckim od XVI do XVIII wieku (Gdańsk: UG, 2001).

2 Zob. Pierre Nora, „Memoire collective”, w Faire d'histoire, red. Jacques Le Goff (Paris: Gallimard 1974), 400; a także m.in. Françoise Choay, The Invention of the Historical Monument (Cambridge: Cambridge University Press, 2001), 47-50. 
różnych zawodów, dla których stawały się one ważnym miejscem pracy. Wielkie kościoły miejskie można więc postrzegać jako miejsca, w których splatały się różnorodne dążenia członków miejskich społeczności - od religijnych po społeczne, polityczne i ekonomiczne, a przeobrażenia architektonicznej struktury oraz stopniowa wymiana wyposażenia odzwierciedlały zachodzące na przestrzeni czasu religijne, społeczne i ekonomiczne przemiany, a także ewolucję artystycznego gustu. Jakkolwiek nie jest to tematem niniejszego przyczynku, warto dodać, że zagadnienie to można rozpatrywać również w znacznie szerszej niż tylko historyczno-artystyczna perspektywie politycznej i społecznej, zwłaszcza że miasto - rozumiane nie jako konkretne miejsce, lecz jako pewien model struktury politycznej, społecznej, ekonomicznej i kulturowej - odegrało ogromną rolę w rozwoju Europy ${ }^{3}$.

Jedną z największych takich budowli na ziemiach dawnej Rzeczpospolitej był nieistniejący dziś kościół pw. św. Marii Magdaleny w Poznaniu. Zrujnowany w drugiej połowie XVIII wieku, a ostatecznie zburzony na przełomie XVIII i XIX stulecia, obiekt ten jest słabo rozpoznany od strony historyczno-artystycznej ${ }^{4}$. Lokalizacja, forma i najwcześniejsze dzieje kościoła parafialnego, którego budowa została uwzględniona w dokumencie lokacyjnym Poznania z 1253 roku, pozostają sporne; nowe światło na te zagadnienia powinny rzucić wyniki najnowszych prac archeologicznych. Według Szczęsnego Skibińskiego kościół został rozbudowany około 1388 roku, kolejne przebudowy miały miejsce po pożarze w roku 1442 oraz około roku 1470, kiedy podniesiono go do rangi kolegiaty 5 . W wyniku tych licznych kampanii budowlanych

3 O modelu tym pisze Pierre Manent, Przemiany rzeczy publicznej. Od Aten do całej ludzkości, tłum. Wiktor Dłuski (Gdańsk: Europejskie Centrum Solidarności, 2014), 27-143.

4 Na jego temat zob. zwłaszcza Szczęsny Skibiński, „Gotycka architektura kościoła farnego pod wezwaniem Marii Magdaleny we Wrocławiu”, w Początki i rozwój Starego Miasta w Poznaniu do XV wieku w świetle nowych badań archeologicznych i urbanistyczno-architektonicznych, red. Włodzimierz Błaszczyk (Poznań: Muzeum Archeologiczne, 1977), 421-437; Szczęsny Skibiński, „Architektura kościołów średniowiecznego Poznania”, w Civitas Posnaniensis. Studia $z$ dziejów średniowiecznego Poznania, red. Zofia Kurnatowska, Tomasz Jurek (Poznań: Wydawnictwo PTPN, 2005), 252-259; Tomasz Jurek, „Wokół zagadek najdawniejszych dziejów poznańskiej fary”, Kronika Miasta Poznania 3 (2003): 46-62. O kościele pisał też Witold Gałka, O architekturze i plastyce dawnego Poznania do końca epoki baroku (Poznań: Wydawnictwo Miejskie, 2001), passim, oraz Witold Gałka, „O architekturze i wystroju kościoła św. Marii Magdaleny”, Kronika Miasta Poznania 3 (2003): 39-45 (artykuł został złożony z fragmentów powyższej książki).

5 O erekcji kolegiaty pisał Paweł Dembiński, „Fundacja i erekcja kolegiaty św. Marii Magdaleny w Poznaniu”, Kronika Miasta Poznania 3 (2003): 63-75. 
budynek otrzymał znaną z ikonografii formę monumentalnej, trójnawowej bazyliki z wielobocznie zamkniętym prezbiterium i wysoką wieżą

Średniowieczny kościół pozostawał centrum życia religijnego miasta również w czasach nowożytnych. W okresie pomyślnego rozwoju Poznania w drugiej połowie XVI oraz w pierwszej połowie XVII wieku do jego wnętrza wprowadzano nowe elementy wyposażenia, fundowane przez korporacje i osoby prywatne lub finansowane z kasy kościelnej. Po splądrowaniu i spaleniu świątyni przez Szwedów w 1657 roku starano się wypełnić ją nowym wyposażeniem. Jednak w XVIII wieku spadł na nią szereg katastrof, skutkujących ostatecznie rozbiórką budowli. W 1725 roku potężna wieża została poważnie uszkodzona przez wiatr, zaś w roku 1773 wybuchł niszczycielski pożar, wywołany uderzeniem pioruna. W odrestaurowanej z dużym wysiłkiem świątyni w 1777 roku zawalił się jeden z filarów, a trzy lata później dzieła zniszczenia dopełnił kolejny pożar. Kiedy w 1798 roku do Poznania przybył Karol Alberti, którego gwasze należą do najważniejszych źródeł ikonograficznych odnoszących się do tej budowli, częściowo zawalony i pozbawiony dachów kościół był już zupełnie zrujnowany. Pozostałe mury ostatecznie rozebrano na polecenie władz pruskich na początku XIX wieku' . Tak uległa zagładzie jedna z najwspanialszych świątyń dawnego Królestwa Polskiego i Rzeczpospolitej Obojga Narodów.

Wyposażenie kościoła w epoce nowożytnej musiało być bardzo bogate. Zapiski wizytacyjne informują o licznych ołtarzach, fundowanych m.in. przez bractwa i rodziny mieszczańskie, w tym Naramowskich, Gieczów i Grodzickich ${ }^{8}$. W będącym główną poznańską nekropolią kościele znajdowało się też wiele epitafiów, upamiętniających przede wszystkim bogatych mieszczan9.

6 Skibiński, „Gotycka architektura”, 430-431, 436-437.

7 Nowożytna historia kościoła za: Magdalena Warkoczewska, „Widoki kolegiaty farnej pw. św. Marii Magdaleny”, Kronika Miasta Poznania 3 (2003): 145-159; zob. też Józef Łukaszewicz, Obraz historyczno-statystyczny miasta Poznania w dawniejszych czasach, t.2 (Poznań: C. A. Pompejusz, 1838), 113-120.

8 Zob. zwłaszcza Archiwum Archidiecezjalne w Poznaniu (dalej: AAP), sygn. AV 1, k. 187-263, Visitatio Archidiaconatus Varsaviensis et Ecclesiae Collegiatae Posnaniensis S. Mariae Magdalenae 1598-1603, Visitatio Ecclesiae Collegiatae Posnaniensis S. Mariae Magdalenae a Laurentio Goślicki eiusque commissariis anno 1602 percata oraz AAP, sygn. AV 5, Wizytacja kościoła kolegiackiego Marii Magdaleny i szpitala św. Ducha w Poznaniu przez biskupa Andrzeja Opaleńskiego, 1618-1622; zob. też Jacek Wiesiołowski, „Kolegiata św. Marii Magdaleny w świetle najstarszej wizytacji”, Kronika Miasta Poznania 3 (2003): 120-144.

9 Łukaszewicz, Obraz, 116; Jacek Wiesiołowski i Rafał Wójcik, „Napisy nagrobne ze starej fary w Monumenta Sarmatarum Szymona Starowolskiego", Kronika Miasta Poznania 3 (2003): 103-119. 
Niestety, większość z nich uległa zniszczeniu w wyniku kolejnych katastrof oraz wandalizmu wojsk szwedzkich i brandenburskich w okresie Potopu. Pod koniec XVIII wieku, gdy kościół popadł w ruinę, ocalałe elementy wystroju uległy rozproszeniu.

Losy kościoła i jego wyposażenia w epoce nowożytnej nie zostały dotąd wyczerpująco omówione. Tym cenniejszym źródłem wiedzy na ten temat jest księga zawierająca wydatki na utrzymanie budowli obejmująca z lat 1612-1652, dotąd niewykorzystana w badaniach nad dziejami poznańskiej fary i jego wyposażenia, a w szerszym kontekście również nad sztuką i architekturą nowożytnego Poznania ${ }^{10}$. Ten bogaty i szczegółowy dokument daje ciekawy wgląd w kilka dekad historii kościoła, zwłaszcza w odniesieniu do powstałych w tym czasie elementów wystroju i urządzeń opłaconych z kasy kościelnej, a także pracujących na jego rzecz artystów i rzemieślników.

Pierwszym rodzajem działań odnotowanych w księdze rachunkowej i istotnych z punktu widzenia trwałości i funkcjonalności kościoła były różnorodne prace budowlane. Ich celem było utrzymanie dobrego stanu technicznego budynku oraz dostosowanie go do zmieniających się potrzeb. Często były to drobne roboty, trwające krótki czas i angażujące niewielu rzemieślników. W 1635 roku naprawiono jeden z filarów kościoła, do czego użyto 300

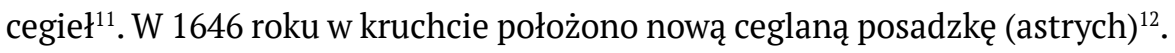
Rok później cieśla imieniem Wojciech naprawiał schody prowadzące na wie$\dot{z ̇}_{e} e^{13}$. Trzeba podkreślić, że w monumentalnych budowlach sakralnych, a także w budynkach rezydencjonalnych (takich jak zamki i pałace) oraz publicznych (zwłaszcza w ratuszach miejskich) prace tego typu, podyktowane przede wszystkim względami technicznymi i funkcjonalnymi, prowadzono niemalże nieustannie.

Zdarzały się też przedsięwzięcia znacznie poważniejsze. W latach 1614-1617 przeprowadzono remont konstrukcji dachowej i wymieniono pokrycie. Materiały budowlane na potrzeby tych prac zbierano już w roku 1612, kiedy zakupiono prawie 4000 dachówek. Powolne gromadzenie materiału wyni-

10 Archiwum Państwowe w Poznaniu (dalej: APP), Akta Miasta Poznania (dalej: AmP), sygn. I/1889, Dochody i wydatki kościoła Marii Magdaleny, 1612-1652 (1664-1677).

11 APP, AmP, sygn. I/1889, Dochody i wydatki kościoła Marii Magdaleny, 1612-1652 (1664-1677), k. 159 r.

12 APP, AmP, sygn. I/1889, Dochody i wydatki kościoła Marii Magdaleny, 1612-1652 (1664-1677), k. 218 .

13 APP, AmP, sygn. I/1889, Dochody i wydatki kościoła Marii Magdaleny, 1612-1652 (1664-1677), k. 222r. 
kało zapewne z niewielkiej mocy produkcyjnej poznańskiej cegielni; trzeba zauważyć, że w omawianym okresie nawet największe cegielnie działające w miastach Rzeczpospolitej wytwarzały najwyżej po kilka tysięcy dachówek rocznie $^{14}$. Pozyskiwano również drewno niezbędne do naprawy więźby dachowej oraz do budowy rusztowań. Na początku przeprowadzono roboty prace ciesielskie, którymi kierował wielokrotnie angażowany przez zarządców kościoła mistrz Lenart Kyncew. Następnie do pracy przystąpił warsztat murarski kierowany przez mistrza Jarosza Nierychłowica. Jego zadaniem była wymiana („przełożenie”) dachówki. Zakres robót wykonanych w 1615 roku określono jako „od wieży aż do krzyżów z obu stron” ${ }^{15}$. W kolejnych latach na bieżąco kupowano dachówkę: w 1615 roku 5,5 tysiąca sztuk, w 1616 roku ponad 3 tysiące sztuk, rok później 2600 sztuk zwykłej dachówki oraz „dachówkę zieloną do krzyżów”. Warto dodać, że w XVII wieku jeszcze trzykrotnie wykonywano różne prace na dachu kościoła: w roku 1640, w roku 1644, kiedy położono nowy dach na wieży (do czego użyto 3900 dachówek oraz blachy miedzianej i żelaznej) oraz w roku $1650^{16}$.

W roku 1622 przeprowadzono poważny remont monumentalnej wieży kościelnej, na której pojawiły się rysy zagrażające jej stabilności. Działający wspólnie murarze i cieśle zamurowali rysy w murze, założyli dębowe i żelazne ankry i naprawili drewnianą konstrukcję. Główne roboty budowlane prowadzili dwaj mistrzowie murarscy, Bartosz Engelman i Tomasz Pulman (Pilman), oraz wspomniany już cieśla Lenart Kyncew $^{17}$. Oprócz tego w przedsięwzięcie zaangażowani byli przedstawiciele innych zawodów, którzy zapewnili niezbędne materiały i narzędzia, w tym kowale, pilarze, bednarz, tokarz i powroźnik. Kowal dostarczył niezbędnych elementów metalowych, w tym ankrów, gwoździ i klamer, bednarz beczek do mieszania wapna, a powroźnik liny do klatki i do windy, do której tokarz osobno wykonał „kółka” ${ }^{18}$.

14 Więcej na ten temat w: Izabela Brzostowska, Franciszek Skibiński: „Uwagi o cegielniach miejskich w Koronie od połowy XVI do połowy XVII", Kwartalnik Historii Kultury Materialnej 4, nr 66 (2018): 459-462.

15 Niestety, wspomniane „krzyże” nie są widoczne na najstarszym znanym widoku kościoła i miasta, pochodzącym z wydanego w 1617 r. VI t. albumu Civitates Orbis Terrarum Georga Brauna i Fransa Hogenberga.

16 APP, AmP, sygn. I/1889, Dochody i wydatki kościoła Marii Magdaleny, 1612-1652 (1664-1677), k. 199r, 213r, 232v-233r.

17 APP, AmP, sygn. I/1889, Dochody i wydatki kościoła Marii Magdaleny, 1612-1652 (1664-1677), k. $69 \mathrm{v}$.

18 APP, AmP, sygn. I/1889, Dochody i wydatki kościoła Marii Magdaleny, 1612-1652 (1664-1677), k. $69 \mathrm{v}-70 \mathrm{r}$. 
Istotne było też zaopatrzenie w materiały. Oprócz elementów żelaznych do naprawy wieży kościelnej zakupiono cegłę, wapno i drewno. Cegły zakupiono 3600 sztuk, prawdopodobnie w cegielni miejskiej, choć brak na to dowodu. Później dokupiono pewną ilość „starej cegły” od niejakiego Achacego Pasamonika ${ }^{19}$. Mogła to być cegła nabyta wcześniej przez tegoż na prywatne potrzeby, jednak niewykorzystana i odsprzedana zarządcom kościoła; poznańscy mieszczanie dokonywali licznych zakupów w cegielni miejskiej ${ }^{20}$. Możliwe jednak, że chodziło tu o nieprodukowaną już wówczas cegłę o rozmiarach gotyckich, pozwalającą na przelicowanie fragmentu muru bez pozostawienia łatwo zauważalnych śladów. Nie sposób oszacować liczby cegieł kupionych od Achacego, a więc i ogółem użytych do prac remontowych, koszty wskazują jednak, że była to liczba nieco większa niż cegieł nabytych wcześniej. Można zatem ostrożnie założyć, że do naprawy wieży użyto około 8-10 tysięcy cegieł. Oprócz cegieł kupowano też drewno, transportowane do miasta drogą wodną, a także wapno. Gdy w trakcie remontu zabrakło wapna, niewielką ilość dokupiono od wykonującego roboty murarza Tomasza Pulmana ${ }^{21}$.

Omawiając prace prowadzone przy wieży kościoła św. Marii Magdaleny warto zwrócić uwagę na prowadzących je mistrzów budowlanych. Bartosz Engelman, prawdopodobnie tożsamy z Bartłomiejem Engelmanem, który przyjął obywatelstwo miejskie w 1618 roku, należał do czynnej w Poznaniu rodziny budowniczych ${ }^{22}$. Pierwszym odnotowanym w mieście jej reprezentantem był mistrz murarski Ditrich Engelman, który obywatelstwo Poznania przyjął w 1600 roku $^{23}$. Ditrich odgrywał ważną rolę w miejscowym środowisku budowlanym, w roku 1603 pełnił funkcję starszego cechu ${ }^{24}$. Co więcej, w 1615 roku został wymieniony wśród przedstawicieli poznańskich murarzy i cieśli w dokumencie potwierdzającym odtworzenie cechu - obok Jarosza Nierychłowica, Feliksa Wesołego i Baltasara Kwikiera; wszyscy oni wielokrot-

19 APP, AmP, sygn. I/1889, Dochody i wydatki kościoła Marii Magdaleny, 1612-1652 (1664-1677), k. 70r.

20 Brzostowska, Skibiński, „Uwagi”, 464-465.

21 APP, AmP, sygn. I/1889, Dochody i wydatki kościoła Marii Magdaleny, 1612-1652 (1664-1677), k. 70r.

22 APP, AmP, sygn. I/273, Album Civitatis Posnanienis 1575-1793, s. 119.

23 APP, AmP, sygn. I/273, Album Civitatis Posnanienis 1575-1793, s. 76.

24 Władze miasta Poznania, red. Jacek Wiesiołowski i Zofia Wojciechowska, t. 1 1253-1793 (Poznań: Wydawnictwo Miejskie, 2003), 177. 
nie pełnili funkcje starszych cechu ${ }^{25}$. Można założyć, że rodzina przybyła do Poznania z Saksonii, gdyż w księdze przyjęć do prawa miejskiego Ditrich Engelman został określony jako murarz drezdeński ${ }^{26}$. W 1647 roku w regestrze bractwa towarzyszów murarskich odnotowano ponadto Krzysztofa Engelmana, pochodzącego z Freiburga ${ }^{27}$ (Freibergu?).

Obecność członków tej rodziny w Poznaniu wpisuje się w szerszą tendencję migracji budowniczych z terenów Saksonii i Śląska do Wielkopolski i dalej do Prus. W końcu XVI i na początku XVII wieku w Poznaniu osiedlali się budowniczowie i kamieniarze z Wrocławia, Głogowa, Świdnicy, w tym wspomniany Baltazar Kwikier, przybyły z Wrocławia ${ }^{28}$. Tamtejszy budowniczowie nierzadko wędrowali jeszcze dalej na północ, docierając np. do Torunia, gdzie ich działalność potwierdzają zapisy w aktach cechu murarskiego ${ }^{29}$. Warto przypomnieć, że już w drugiej połowie XVI wieku murarze z miast śląskich i saskich pracowali nawet w Gdańsku, współpracując m.in. z pochodzącym z Drezna mistrzem Hansem Kramerem ${ }^{30}$. Jedną z przyczyn ich migracji był zapewne żywy rozwój murarstwa i kamieniarstwa na Śląsku i w Saksonii, co przekładało się na wysoką liczbę wykwalifikowanych rzemieślników.

Mniej można powiedzieć o drugim z murarzy zaangażowanych w naprawę farnej wieży - Tomaszu Pulmanie. Wiadomo, że w roku 1621, a więc rok przed podjęciem remontu w kościele, był jednym ze starszych poznańskiego cechu murarskiego ${ }^{31}$. Do niego i jego pomocników może odnosić się zapis o wypłacie wynagrodzenia za udział w przygotowaniach do królewskiego wjazdu w 1623 roku $^{32}$; do jego czeladników należeliby wtedy murarze, którym

25 Witold Meisel, Wilkierze poznańskie, t. 3 Organizacja cechowa (Wrocław-Warszawa-Kraków: Ossolineum, 1969), 106-107. Odnośnie do pełnienia funkcji w cechu przez tych trzech mistrzów zob. Władze miasta Poznania, 170, 172, 176, 180, 181, 183-186, 192, 194, 196, 197, 199-201. APP, AmP, sygn. I/273, Album Civitatis Posnanienis 1575-1793, s. 76.

27 Stanisław Wiliński, „Regestr czeladników i mistrzów cechu muratorów w Poznaniu z lat 1618-1679”, Przegląd Zachodni 9, nr 9-10 (1953): 227.

28 Wiliński, „Regestr”, 227; zob. też APP, AmP, sygn. I/273, Album Civitatis Posnanienis 1575-1793, s. 10, 38, 63, 76, 82, 124.

29 Archiwum Państwowe w Toruniu, Kat. IV, Cech murarzy 3, Księga protokołów mistrzów cechu murarskiego (1572-1821), passim.

30 Franciszek Skibiński, „Architekci, budowniczowie, kamieniarze i rzeźbiarze obcego pochodzenia w Gdańsku 1550-1630. Szkic z dziejów migracji artystycznej”, Biuletyn Historii Sztuki 77, nr 1 (2015): 9-10.

$31 \quad$ Władze miasta Poznania, 197.

32 APP, AmP, sygn. I/868, Księga szafarska, 1622-1623, k. 32v. 
jako zachętę do lepszej pracy dano dodatkowe pieniądze „na przepicie”33. Mistrz Tomasz byłby więc typowym reprezentantem miejskiego rzemiosła budowlanego, wykonującym różne bieżące prace m.in. na rzecz miasta i kościoła farnego.

W okresie ujętym w księdze rachunkowej do wnętrza kościoła św. Marii Magdaleny wprowadzono też kilka nowych elementów wyposażenia. Pierwszym poważnym przedsięwzięciem podjętym w tym czasie i finansowanym $\mathrm{z}$ kasy fabrica ecclesia była budowa monumentalnego cyborium z kamiennymi elementami rzeźbiarskimi. W 1622 roku proboszcz wspólnie z witrykami i za pozwoleniem burmistrzów zawarł umowę ze snycerzem Krzysztofem na wykonanie cyborium z „różniastego kamienia” ${ }^{34}$; trzeba dodać, że w ówczesnym Poznaniu snycerzami nazywano rzeźbiarzy pracujących zarówno w drewnie, jak i w kamieniu. Przewidywany koszt nowego cyborium miał wynieść 2300 zł, co w przybliżeniu odpowiadało rocznym dochodom kościoła w tym czasie i stanowiło około $10 \%$ ówczesnych rocznych dochodów miasta $^{35}$. Wydaje się, że w tym czasie, chociaż przy kościele funkcjonowała kapituła kolegiacka, nadzór nad jego finansami i prowadzonymi w nim pracami najwyraźniej sprawowali nadal witrycy wspólnie z proboszczem, będącym zarazem członkiem kapituły ${ }^{36}$. Trudno jednak na podstawie jednostkowych przypadków wysuwać ostateczne wnioski ${ }^{37}$.

Prace przy cyborium ruszyły dopiero w roku 1627, po pięciu latach od spisania kontraktu z rzeźbiarzem ${ }^{38}$. Opóźnienie mogło wynikać m.in. z konieczności przeprowadzenia w roku zawarcia umowy wspomnianego wyżej

33 APP, AmP, sygn. I/868, Księga szafarska, 1622-1623, k. 33v.

34 APP, AmP, sygn. I/1889, Dochody i wydatki kościoła Marii Magdaleny, 1612-1652 (1664-1677), k. 68 r.

35 Np. w roku rachunkowym 1620/1621 dochód miasta wyniósł niewiele ponad 20 tys. zł, APP, AmP, sygn. I/864, Rachunki szafarskie, k. 7r. Dla całego okresu 1612-1620 było to średnio 21 978 zł, natomiast dla dziesięciolecia 1621-1630 - 21304 zł, zob. Jerzy Kądziołka, Finanse miasta Poznania 1501-1648 (Poznań: Poznańskie Wydawnictwo Naukowe, 1960), tabela 49.

36 O roli witryków zob. np. Christofer Herrmann, „Die Kirchenväter der Danziger Marienkirche. Stellung, Aufgaben und Wirken vom 14. bis zum Anfang des 17. Jahrhunderts“, w Chronik der Marienkirche in Danzig. Das „Historische Kirchen Register“ von Eberhard Bötticher (1616). Transkription und Auswertung, red. Christofer Herrmann i Edmund Kizik (Köln: Böhlau Verlag, 2013), 115-204.

37 W Archiwum Archidiecezjalnym w Poznaniu znajduje się obszerny zespół akt kapituły kolegiackiej, niestety nieskatalogowany. Za konsultacje serdecznie dziękuję kustoszowi archiwum, ks. mgr. Rafałowi Rybackiemu.

38 APP, AmP, sygn. I/1889, Dochody i wydatki kościoła Marii Magdaleny, 1612-1652 (1664-1677), k. $114 \mathrm{v}-115 \mathrm{v}$. 
nagłego remontu grożącej zawaleniem wieży kościelnej. W pierwszym sezonie wykonano główne roboty budowlane, w które zaangażowani byli murarz, cieśla i snycerz, a ponadto grabarz i rzemieślnicy dostarczający materiału i narzędzi. Na początku zgromadzono potrzebne materiały konieczne do prac murarskich, w tym cegłę, wapno i piasek (na tym etapie odnotowano też wypłaty dla murarza) oraz deski i drewno dębowe „do gruntu”, a więc na fundament pod nowe cyborium. Następnie cieśla z pomocnikami zbudował nowy ołtarz „pośrodku kościoła”, prawdopodobnie tymczasowy, po czym rozebrano stare cyborium. Nadal gromadzono materiał budowlany, w tym żelazo, drewno, wapno, piasek i ponad 20 tysięcy cegieł. Mając przygotowane materiały podjęto główne roboty - wykonano m.in. sklepione, przynajmniej częściowo zagłębione w ziemi pomieszczenie przed ołtarzem, wykorzystując dostarczone przez snycerza kamienne elementy, położono też posadzkę z glazurowanych płytek ceramicznych. Prace kontynuowano w kolejnym roku, jednak na dużo mniejszą skalę. W tym czasie sprowadzono i zamontowano kamienne rzeźby ewangelistów i aniołów, murarz zaś wymurował stopnie schodów ${ }^{39}$. Ostatnie wypłaty dotyczące cyborium odnotowano w roku $1629^{40}$.

Głównym wykonawcą prac był poznański rzeźbiarz Krzysztof Redel, który zawarł wspomnianą umowę z władzami kościoła w 1622 roku i został kilkakrotnie odnotowany w rachunkach odnoszących się do budowy nowego cyborium $^{41}$. Snycerz Krzysztof, zapewne tożsamy z Redelem, pracował na rzecz kościoła św. Marii Magdaleny już wcześniej. Przykładowo, w 1615 roku otrzymał wynagrodzenie za „rzezanie figur do form i herbów na wierzch” (chodziło tu o herby królewski i miejski ${ }^{42}$; na podstawie lakonicznych wzmianek nie sposób jednoznacznie określić przeznaczenia tych detali. Figury i herby zostały następnie pozłocone przez anonimowego malarza.

Udział Redela w pracach przy cyborium potwierdza ponadto opublikowany przez Alfreda Brosiga testament rzeźbiarza, którego fragment warto tu przytoczyć: „Panowie kościelny farscy tutejsi, zostali my reszty od cyborium złotych dwieście, do którego cyborium miałem jeszcze zrobić obraz miłosier-

39 APP, AmP, sygn. I/1889, Dochody i wydatki kościoła Marii Magdaleny, 1612-1652 (1664-1677), k. $120 \mathrm{v}-121 \mathrm{r}$.

40 APP, AmP, sygn. I/1889, Dochody i wydatki kościoła Marii Magdaleny, 1612-1652 (1664-1677), k. 122r.

41 APP, AmP, sygn. I/1889, Dochody i wydatki kościoła Marii Magdaleny, 1612-1652 (1664-1677), k. $120 \mathrm{v}-121 \mathrm{r}$.

42 APP, AmP, sygn. I/1889, Dochody i wydatki kościoła Marii Magdaleny, 1612-1652 (1664-1677), k. 27r. 
dzia, który, gdy dadzą w Gdańsku zrobić, zapłaciwszy jako go stargują, ostatek oddadzą małżonce mojej" ${ }^{43}$. Jego zaangażowanie nie dziwi, był on bowiem doświadczonym rzeźbiarzem i ważną postacią miejscowego środowiska artystycznego ${ }^{44}$. Pochodzący z Würzburga rzeźbiarz, syn reprezentującego tę samą profesję Hansa Redela (Retel, Rödle), przybył do Poznania na przełomie XVI i XVII wieku. W 1605 roku ożenił się z Anną, wdową po wywodzącym się z Królewca rzeźbiarzu Gabrielu Kopsie, który w roku 1592 otrzymał obywatelstwo miejskie i odgrywał znaczącą rolę w mieście nad Wartą, wielokrotnie pełniąc funkcję starszego cechu ${ }^{45}$. Sądząc po charakteryzującej przednowoczesne społeczeństwa praktyce łączenia życia zawodowego z osobistym, Redel był prawdopodobnie związany z warsztatem Kopsa. Utrzymywał też relacje z innymi artystami czynnymi w Poznaniu; np. był jednym z opiekunów synów malarza Andrzeja Stussa ${ }^{46}$. Rzeźbiarz pracował dla różnych zleceniodawców i zapewne cieszył się poważaniem w regionie, o czym świadczy szereg ważnych realizacji. Około 1613 roku wykonał rzeźby Jowisza, Neptuna, Apollona i Marsa do czterech studni na poznańskim rynku, widocznych na najstarszym znanym widoku Poznania opublikowanym w Civitates Orbis Terrarum Georga Brauna i Fransa Hogenberga ${ }^{47}$. Nieco później, w 1621 roku, zawarł kontrakt z poznańskimi dominikanami na budowę drewnianego ołtarza do kaplicy różańcowej. Pod koniec życia wykonał ołtarz dla Samuela Waszowskiego i trzy ołtarze dla paradyskich cystersów. Określany jako „lapicida” oraz „snycerz”, Redel pracował zarówno w drewnie, jak i w kamieniu.

Biorąc pod uwagę skalę i materiał, monumentalne cyborium do kościoła św. Marii Magdaleny należało do najważniejszych dzieł jego pracowni. W jego realizację zaangażowani byli też jednak inni twórcy - według słów samego Redela przynajmniej niektóre rzeźbiarskie elementy cyborium miały zostać bowiem wykonane w Gdańsku. Informacja ta nie tylko potwierdza znaczenie

43 Alfred Brosig, Materjały do historji sztuki wielkopolskiej (Poznań: [s.n.], 1934), 139-141.

44 O nim Brosig, Materjały, 137-141; Eugeniusz Linette, „Kontrakty dominikanów poznańskich ze snycerzami pozn. (Krzysztofem Redellem z 1621 i Fr. Antonim Brumbacherem z 1714 roku)”, Biuletyn Historii Sztuki 28, nr 3-4 (1966): 388-392; Maria Heydel, „Redel (Redell, Reidell, Retel, Ryder) Krzysztof", w Słownik artystów polskich i w Polsce pracujących. Malarze, rzeźbiarze, graficy, t. 8, red. Urszula Makowska i Katarzyna Mikocka-Rachubowa (Warszawa: IS PAN, 2007), 264-265.

45 Brosig, Materjały, 11, 106-107. Kops nie był jedynym rzeźbiarzem przybyłym z Królewca czynnym w tym czasie w Poznaniu, z Królewca pochodził Sebastian Sandenbrück, który również zajmował się rzeźbą figuralną (statuarius); zob. Brosig, Materjały, 131-135.

46 Brosig, Materjały, 127-128.

47 Brosig, Materjaty, 138. 
tego ośrodka dla sztuki na ziemiach ówczesnej Rzeczpospolitej, ale przede wszystkim ukazuje złożoność procesu wytwarzania monumentalnych dzieł rzeźbiarskich. Na podstawie zapisu w jego testamencie można przyjąć, że Redel sprawował ogólny nadzór nad wykonaniem rzeźbiarskich partii cyborium, a prawdopodobnie również nad pozostałymi pracami związanymi z tym przedsięwzięciem. Witrycy kościoła farnego - tak zapewne należy interpretować określenie „panowie kościelni” - zdecydowali się powierzyć to zadanie rzeźbiarzowi przebywającemu na miejscu, co z pewnością ułatwiało kontrolę. Jako doświadczony rzeźbiarz, czynny w zawodzie od wielu lat, Redel był z pewnością gotów do podjęcia się tak odpowiedzialnych obowiązków, prowadząc zaś warsztat rzeźbiarski mógł nie tylko nadzorować prace, ale też wykonać wiele elementów cyborium. Wzmianka o sprowadzeniu elementów rzeźbiarskich z Gdańska wskazuje jednocześnie, że będąc kierownikiem projektu Redel zlecał realizację pewnych prac w innych warsztatach, działających w Gdańsku. Przypomina to praktykę znaną już z XVI wieku - np. Willem van den Blocke, pracując nad pomnikiem pary książęcej w Królewcu i borykając się z brakiem odpowiednio wyszkolonych pomocników, zamówił elementy rzeźbiarskie w pracowni czynnego w tym czasie w Gdańsku rzeźbiarza Hansa Steffena ${ }^{48}$. Warto przypomnieć, że z bałtyckiej metropolii sprowadzano do Wielkopolski wiele innych dzieł rzeźbiarskich, wśród nich m.in. portale chóru katedry gnieźnieńskiej i - najprawdopodobniej - wyposażenie kaplicy Kołudzkich w tym samym kościele ${ }^{49}$.

Monumentalne cyborium z kamiennymi rzeźbami najprawdopodobniej uległo zniszczeniu już w czasie Potopu. W 1657 roku wojska szwedzkie i brandenburskie podpaliły splądrowany wcześniej kościół św. Marii Magdaleny, o czym wspomniano w aktach wizytacji z lat $1695-1697^{50}$. Można podejrzewać, że służące kultowi eucharystycznemu cyborium stało się dla protestanckich żołnierzy szczególnym celem. Wspomniana wizytacja nie odnotowuje

48 Franciszek Skibiński, Willem van den Blocke. Niderlandzki rzeźbiarz na Bałtykiem w XVI i na początku XVII wieku (Toruń: TNT, 2015), 52-53.

49 Odnośnie do katedry zob. Lech Krzyżanowski, „Portale w arkadach prezbiterium”, w Katedra gnieźnieńska, red. Aleksandra Świechowska (Poznań: Księgarnia św. Wojciecha, 1970), 308-309; odnośnie do kaplicy zob. Stefan Damalewicz, Series Archiepiscoporum Gnesnensium, typis Petri Elert, Varsoviae 1649, s. 31, przywołane też w: Franciszek Skibiński, „Rzeźba kamienna w Toruniu ok. 1580-1650. Pomiędzy produkcją miejscową a importem z czołowych ośrodków rzeźbiarskich Rzeczypospolitej”, w Stare i nowe dziedzictwo Torunia, red. Juliusz Raczkowski (Toruń: Wydział Sztuk Pięknych UMK, 2013), 217-218.

50 AAP, sygn. AV 18, Visitatio Archidiaconatus Posnaniensis a Nicolao Zalaszowski archidiacono a. $1695-1696$ peracta, $k$. 73 r. 
już jego istnienia, podaje natomiast, że drewniane cyborium znajduje się w głównym ołtarzu kościoła ${ }^{51}$. Wizytator opisał tu z pewnością nowy ołtarz, wykonany w latach 1670-1672; kontrakt na jego budowę zawarli w 1670 roku kanonik i proboszcz Stefan Moręski i snycerz Jan Hanusik (Anusik) ${ }^{52}$. Nowa, monumentalna struktura o trójkondygnacyjnej, architektonicznej kompozycji, wykonana - jak zapisano we wspomnianym kontrakcie - „według kunsztu architektury civilis”, zastąpiła nastawę zniszczoną przez Szwedów w 1657 roku. Ta zaś mogła być tożsama z nastawą odnotowaną w wizytacji z 1602 roku, która według Jacka Wiesiołowskiego miała być jeszcze średniowiecznym tryptykiem ${ }^{53}$. Jest to hipoteza o tyle prawdopodobna, że księga rachunkowa kościoła nie zawiera informacji o budowie nowego ołtarza głównego. Oznaczałoby to, że aż do połowy XVII wieku w jednym z największych i najbogatszych kościołów miejskich Rzeczpospolitej w ołtarzu głównym było średniowieczne retabulum ${ }^{54}$.

Po ukończeniu cyborium zdecydowano się na jeszcze bardziej kosztowne przedsięwzięcie - mianowicie na budowę nowych organów w zachodniej części kościoła. Rozpoczęte w 1632 roku prace trwały pięć lat, a kierował nimi budowniczy organów Walenty Mniszek..$^{55}$ Zanim do nich przystąpiono, mistrz Walenty dokonał oględzin dotychczas używanego instrumentu i oceny jego stanu. Wkrótce potem wzniesiono rusztowanie i rozebrano stare organy ${ }^{56}$. W latach 1632-1633 wykonano prace murarskie, na potrzeby których zakupiono kilka tysięcy cegieł, oraz ciesielskie, do których nabyto spore ilości drewna ${ }^{57}$. Chodziło zapewne o budowę nowej empory organowej. W tym

51 AAP, sygn. AV 18, Visitatio Archidiaconatus Posnaniensis a Nicolao Zalaszowski archidiacono a. $1695-1696$ peracta, $\mathrm{k} .73 \mathrm{v}$.

52 Marja Wicherkiewiczowa, Rynek poznański i jego patrycjat, (Poznań: Wydawnictwo Miejskie, 1998), 50-51; Brosig, Materjały, 25-52; Gałka, „O architekturze i wystroju”, 44-45 (tu błędne daty wykonania ołtarza: 1660-1662).

53 Wiesiołowski, „Kolegiata”, 122.

54 Por. Grażyna Jurkowlaniec, Epoka nowożytna wobec średniowiecza. Pamiątki przeszłości, cudowne wizerunki, dzieła sztuki (Wrocław: Wydawnictwo UWr, 2008), 152, 164-171.

55 Nie został on odnotowany w podstawowych opracowaniach dotyczących historii budowy organów w Polsce, patrz: Jerzy Gołos, Zarys historii budowy organów w Polsce (Bydgoszcz: Bydgoskie Towarzystwo Naukowe, 1966); Jerzy Gołos, Polskie organy i muzyka organowa (Warszawa: Instytut Wydawniczy PAX, 1972); Ewa Smulikowska, Prospekty organowe w dawnej Polsce (Wrocław-Warszawa-Kraków-Gdańsk-Łódź: Ossolineum, 1989).

56 APP, AmP, sygn. I/1889, Dochody i wydatki kościoła Marii Magdaleny, 1612-1652 (1664-1677), k. $143 \mathrm{v}$.

57 APP, AmP, sygn. I/1889, Dochody i wydatki kościoła Marii Magdaleny, 1612-1652 (1664-1677), k. $150 \mathrm{r}-151 \mathrm{r}$. 
czasie mistrz Walenty najprawdopodobniej skonstruował nowy instrument, wtedy bowiem otrzymał bardzo wysokie wynagrodzenie za swoją pracę. Prospekt musiał być gotowy w 1635 roku, w tym czasie bowiem zamontowano na nim figury przedstawiające św. Piotra i św. Pawła ${ }^{58}$. Podobnie jak cała robota rzeźbiarska przy nowym prospekcie, były one dziełem snycerza imieniem Konrad (Condrat), zaangażowanego w budowę nowych organów w latach 1633-1636, przy czym - sądząc po wysokości wypłat - gros prac snycerskich przypadło na lata 1634-1635, czyli czas, gdy gotowa była już empora i struktura nowego prospektu ${ }^{59}$.

Wspomniany snycerz Konrad to zapewne Konrad Pot, kolejny obok Krzysztofa Redela poznański rzeźbiarz zatrudniony przy pracach prowadzonych w farze. Pochodził z Salzufflen w księstwie Lippe-Detmold i przyjął prawo miejskie w 1634 roku, a więc gdy pracował przy prospekcie dla kościoła św. Marii Magdaleny ${ }^{60}$. Przed przybyciem do Poznania Pot, określany w źródłach jako „sculptor” i „Bildschnitzer”, wykonał m.in. kilka pomników nagrobnych we Wschowie i być może w innych miejscach, natomiast później, już w stolicy Wielkopolski, m.in. figury do fontanny na rynku (około 1644 roku). Zgodnie z zapisami w testamencie, miał on też zbudować ołtarz zamówiony przez Jakuba Heldenfingera oraz cyborium do kościoła w Lwówku. Warta przypomnienia jest także podróż jego syna, Ezajasza Pota, do Gdańska, dokąd udał się na naukę zawodu snycerskiego, po raz kolejny potwierdzająca relacje pomiędzy tymi ośrodkami ${ }^{61}$. Podobnie jak Krzysztof Redel, Pot pracował zarówno w kamieniu - czego dowodem są płyty nagrobne we Wschowie - jak i w drewnie, na co wskazuje również wzmianka w testamencie o znajdujących się w jego warsztacie narzędziach i materiałach ${ }^{62}$. Na marginesie obecnych rozważań można dodać, że testament Pota dostarcza innych ważnych informacji o ówczesnej praktyce warsztatowej, z których najistotniejsza dotyczy dwóch pudeł „gipsowych modliów albo form” oraz wielkiego pudła

58 APP, AmP, sygn. I/1889, Dochody i wydatki kościoła Marii Magdaleny, 1612-1652 (1664-1677), k. $160 \mathrm{v}$.

59 APP, AmP, sygn. I/1889, Dochody i wydatki kościoła Marii Magdaleny, 1612-1652 (1664-1677), k. 151r, 155r, 160r-160v, 166v.

60 O nim Brosig, Materjały, 207-217; Jan Harasimowicz, „Związki artystyczne Wielkopolski i Śląska w zakresie rzeźby kamiennej w XVI i 1 poł. XVII wieku”, Biuletyn Historii Sztuki 53, nr 3-4 (1991): 209-210, 220; Maria Heydel, „Pot (Bothe, Pothe, Rot) Konrad”, w Słownik artystów polskich i w Polsce pracujących. Malarze, rzeźbiarze, graficy, t. 7, red. Urszula Makowska (Warszawa: IS PAN, 2003), 429-430.

61 Brosig, Materjały, 213-214, 244.

62 Brosig, Materjały, 212. 
„modliów albo form woskowych”33. Przekaz ten poświadcza powszechność stosowania tego rodzaju narzędzi projektowych w pracowniach rzeźbiarskich w tym czasie $^{64}$.

Po wzniesieniu prospektu i zakończeniu prac snycerskich wykonano dekorację malarską oraz położono srebrzenia i złocenia - na ten cel zakupiono dużą ilość srebra i złota. Zadanie to wykonali malarze Jakub Stephan (Steffan, Stepsen) i Jerzy Langner ${ }^{65}$. Pochodzący z Królewca Jakub Stephan pojawił się w Poznaniu już w roku 1613, a w 1624 roku przyjął tamtejsze obywatelstwo. Będąc wielokrotnie starszym cechu - w latach 1631, 1633-1634, 1636, 1639-1641, 1645-1652 oraz 1654 - zapewne odgrywał ważną rolę w miejscowym środowisku ${ }^{66}$. O drugim z malarzy, Jerzym Langnerze, wiadomo bardzo niewiele. Alfred Brosig przytacza jedynie kilka informacji dotyczących jego rodziny i spraw majątkowych ${ }^{67}$; oskarżenie o lżenie religii katolickiej wskazuje na protestanckie sympatie malarza, być może przybysza z Prus lub Śląska. Wydaje się, że Jakub Stephan i Georg Langner byli ze sobą dość blisko związani, ich nazwiska pojawiają się bowiem obok siebie w kilku sprawach. Choć w trakcie prac przy organach występowali osobno, przynajmniej dwukrotnie otrzymali wspólne wynagrodzenie, co również sugeruje pewną formę współpracy ${ }^{68}$.

Roboty ostatecznie ukończono w 1637 roku. Mistrzowi Walentemu, głównemu budowniczemu organów, wypłacono wynagrodzenie za dokończenie prac, malarzom Jakubowi Stephanowi i Jerzemu Langnerowi zapłacono za malowanie, srebrzenie i złocenie prospektu, chłopom zaś za zdjęcie rusztowań ${ }^{69}$. Budowa nowego prospektu była przedsięwzięciem jeszcze bardziej kosztownym od cyborium. W sumie wydano na ten cel około 4500 zł, przy

63 Brosig, Materjały, 212.

64 Odnośnie do modeli rzeźbiarskich zob. m.in. Konstanty Kalinowski, „Warsztat barokowego rzeźbiarza”, Artium Questiones 7 (1995): 113-120, a w kontekście europejskim m.in. Triumph der Phantasie. Barocke Modelle von Hilderbrandt bis Mollinarolo, red. Michael Krapf (Wien: Böhlau, 1998), oraz Johannes Myssok, Bildhauerische Konzeption und plastisches Modell in der Renaissance (Münster: Rhema, 1999).

65 APP, AmP, sygn. I/1889, Dochody i wydatki kościoła Marii Magdaleny, 1612-1652 (1664-1677), k. $174 \mathrm{v}, 175 \mathrm{r}$.

66 Brosig, Materjały, 11-12, 152-157.

67 Brosig, Materjały, 179-181.

68 APP, AmP, sygn. I/1889, Dochody i wydatki kościoła Marii Magdaleny, 1612-1652 (1664-1677), k. $166 \mathrm{r}, 175 \mathrm{r}$.

69 APP, AmP, sygn. I/1889, Dochody i wydatki kościoła Marii Magdaleny, 1612-1652 (1664-1677), k. $174 \mathrm{r}, 175 \mathrm{r}$. 
czym największe wydatki - łącznie 2618 zł - poniesiono w dwóch pierwszych latach prac, z czego niemal połowę (bo aż 1254 zł) zapłacono mistrzowi Walentemu. Jego wynagrodzenie wyniosło w ciągu tych dwóch lat niewiele mniej niż koszty pracy wszystkich innych rzemieślników i robotników oraz zakup materiałów, co jasno ukazuje bardzo silną pozycję wysoko wykwalifikowanego specjalisty, dysponującego rzadkimi umiejętnościami. Wynagrodzenie innych rzemieślników było dużo niższe. Rzeźbiarz Konrad Pot za prace snycerskie otrzymał łącznie 322 zł, natomiast malarze Jakub i Jerzy - choć głównie ten pierwszy - za wykonanie polichromii, złoceń i srebrzeń 338 zł.

Oprócz wielkich i kosztownych przedsięwzięć, angażujących wielu rzemieślników i robotników, wykonywano też obiekty o dużo skromniejszym charakterze. Nierzadko były one jednak bardzo istotne z punktu widzenia funkcji kościoła i wspólnoty. Należały do nich tymczasowe elementy wyposażenia służące oprawie świąt liturgicznych, takie jak drewniany baldachim nad Grobem Świętym, wznoszony corocznie z okazji obchodów Wielkiego Piątku. W latach 1622 i 1623 za jego budowę odpowiadał cieśla Lenart Kyncew, wielokrotnie pracujący w miejskiej farze.

Warto też wspomnieć o innej inwestycji. W 1619 roku do głównego portalu kościoła sprawiono nowe, reprezentacyjne drzwi z miedzianym okuciem. Najpierw zakupiono deski, z których cieśla wykonał skrzydła drzwiowe. Następnie z Wrocławia sprowadzono dwa i pół centnara miedzi, za które opłacono cesarskie cło; miedź do Poznania wysłał Krzysztof Tym. Do obicia nią drzwi już w Poznaniu zaangażowano miejscowego kotlarza Hanusza. Nabyto również rygle, gwoździe i skoble. Kowal Młodawski odkuł zawiasy i haki służące do zawieszenia drzwi. Skrzydła drzwiowe otrzymały dekorację w formie dwóch herbów, wykonanych przez złotnika Bartosza; osobno zakupiono do nich złoto i smołę. Zaangażowano też murarza Jarosza, którego zadaniem było wmurowanie haków do zawieszenia drzwi; był to zapewne mistrz Jarosz Nierychłowic, wielokrotny starszy cechu, choć tę prostą robotę prawdopodobnie wykonał któryś z jego pomocników ${ }^{70}$. Łącznie za drzwi zapłacono nieco ponad 213 zł, z czego najwięcej za kupioną we Wrocławiu miedź (81 zł) oraz obicie nią drzwi (37 zł); złotnik za wykonanie herbów otrzymał już znacznie mniej, bo tylko 14 zł, ponadto wydano 5 zł na złoto. Całkowity koszt

70 Wiliński, „Regestr”, 211-235; Władze miasta Poznania, passim. 
nowych drzwi był jednak dość znaczny, odpowiadał np. rocznym dochodom dość dużego miejskiego młyna Bogdanka ${ }^{71}$.

Podsumowując należy podkreślić, że informacje zaczerpnięte z księgi rachunkowej kościoła pw. św. Marii Magdaleny w Poznaniu pozwalają poszerzyć wiedzę o dziejach tej świątyni oraz jej wyposażeniu w okresie rozwoju miasta w pierwszej połowie XVII wieku. Spostrzeżenie to odnosi się w szczególności do dwóch ważnych obiektów, które w tym czasie dużym nakładem kosztów sprawiono do kościoła - mianowicie monumentalnego cyborium z kamienną dekoracją rzeźbiarską, powstałego w latach 1627-1629, oraz prospektu organowego, wykonanego w latach 1632-1637. Rachunki dotyczące prac budowlanych uzupełniają ponadto wiedzę o ówczesnym rzemiośle budowlanym. Wobec niewielkiej ilości źródeł tego typu rachunki poznańskiej fary mogą ilustrować sposob postępowania w innych dużych kościołach miejskich dawnej Rzeczpospolitej.

Równie istotne poznawczo są wzmianki o artystach i rzemieślnikach wykonujących prace na rzecz kościoła. Analiza rachunków, uzupełniona wiadomościami czerpanymi z innych źródeł, zarówno publikowanych, jak i niepublikowanych, ujawniła nieznane dotąd informacje dotyczące poznańskich rzeźbiarzy, malarzy i budowniczych, w tym tak ważnych postaci miejscowego środowiska, jak Krzysztof Redel i Konrad Pot. Byli oni angażowani do różnorodnych prac na rzecz kościoła, uczestnicząc tym samym w przedsięwzięciach istotne dla społeczności miejskiej. Warto spojrzeć na ich działalność nie tylko przez pryzmat wartości estetycznych bądź praktycznych aspektów ich pracy, ale również w kontekście społecznego znaczenia ich dzieł. Pracując w farze miejscy artyści i rzemieślnicy, nawet ci wykonujący proste i z pozoru oczywiste prace, współtworzyli przestrzeń kształtującą miejską wspólnotę.

\section{Bibliografia}

Brosig, Alfred. Materjały do historji sztuki wielkopolskiej. Poznań: [s.n.] 1934.

Brzostowska, Izabela, i Franciszek Skibiński. „Cegielnie miejskie w Koronie od połowy XVI do połowy XVII w.”. Kwartalnik Historii Kultury Materialnej 4, nr 66 (2018): 449-474.

Choay, Françoise. The Invention of the Historical Monument. Cambridge: Cambridge University Press, 2001.

71 APP, AmP, sygn. I/876, Księga szafarska 1629-1630, k. 9r. 
Dembiński, Paweł. „Fundacja i erekcja kolegiaty św. Marii Magdaleny w Poznaniu”. Kronika Miasta Poznania 3 (2003): 63-75.

Gałka, Witold. O architekturze i plastyce dawnego Poznania do końca epoki baroku. Poznań: Wydawnictwo Miejskie, 2001.

Gałka, Witold. „O architekturze i wystroju kościoła św. Marii Magdaleny”. Kronika Miasta Poznania 3 (2003): 39-45.

Gołos, Jerzy. Zarys historii budowy organów w Polsce. Bydgoszcz: Bydgoskie Towarzystwo Naukowe, 1966.

Gołos, Jerzy. Polskie organy i muzyka organowa. Warszawa: Instytut Wydawniczy PAX, 1962.

Harasimowicz, Jan. „Związki artystyczne Wielkopolski i Śląska w zakresie rzeźby kamiennej w XVI i 1 poł. XVII wieku”. Biuletyn Historii Sztuki 53, nr 3-4 (1991): 201-225.

Herrmann, Christofer. „Die Kirchenväter der Danziger Marienkirche. Stellung, Aufgaben und Wirken vom 14. bis zum Anfang des 17. Jahrhunderts“. W Chronik der Marienkirche in Danzig. Das „Historische Kirchen Register“ von Eberhard Bötticher (1616). Transkription und Auswertung, red. Christofer Herrmann i Edmund Kizik, 115-204. Köln: Böhlau Verlag, 2013.

Heydel, Maria. „Pot (Bothe, Pothe, Rot) Konrad”. W Słownik artystów polskich i w Polsce pracujących. Malarze, rzeźbiarze, graficy. T. 7, red. Urszula Makowska, 429-430. Warszawa: IS PAN, 2003.

Heydel, Maria. „Redel (Redell, Reidell, Retel, Ryder) Krzysztof”. W Słownik artystów polskich i w Polsce pracujących. Malarze, rzeźbiarze, graficy. T. 8, red. Urszula Makowska, Katarzyna Mikocka-Rachubowa, 264-265. Warszawa: IS PAN, 2007.

Jurek, Tomasz. „Wokół zagadek najdawniejszych dziejów poznańskiej fary”. Kronika Miasta Poznania 3 (2003): 46-62.

Jurkowlaniec, Grażyna. Epoka nowożytna wobec średniowiecza. Pamiątki przeszłości, cudowne wizerunki, dzieła sztuki. Wrocław: Wydawnictwo UWr, 2008.

Kalinowski, Konstanty. „Warsztat barokowego rzeźbiarza”. Artium Questiones 7 (1995): $103-140$.

Kądziołka, Jerzy. Finanse miasta Poznania 1501-1648. Poznań: Poznańskie Wydawnictwo Naukowe, 1960.

Kizik, Edmund. Wesele, kilka chrztów i pogrzebów. Uroczystości rodzinne w mieście hanzeatyckim od XVI do XVIII wieku. Gdańsk: UG, 2001.

Krzyżanowski, Lech. „Portale w arkadach prezbiterium”. W Katedra gnieźnieńska, red. Aleksandra Świechowska, 308-309. Poznań: Księgarnia św. Wojciecha, 1970.

Linette, Eugeniusz. „Kontrakty dominikanów poznańskich ze snycerzami pozn. (Krzysztofem Redellem z 1621 i Fr. Antonim Brumbacherem z 1714 roku)”. Biuletyn Historii Sztuki 28, nr 3-4 (1966): 388-392.

Łukaszewicz, Józef. Obraz historyczno-statystyczny miasta Poznania w dawniejszych czasach. T. 2. Poznań: C. A. Pompejusz, 1838. 
Manent, Pierre. Przemiany rzeczy publicznej. Od Aten do całej ludzkości. Tłumaczenie Wiktor Dłuski. Gdańsk: Europejskie Centrum Solidarności, 2014.

Meisel, Witold. Wilkierze poznańskie. T. 3 Organizacja cechowa. Wrocław-Warszawa-Kraków: Ossolineum, 1969.

Myssok, Johannes. Bildhauerische Konzeption und plastisches Modell in der Renaissance. Münster: Rhema, 1999.

Nora, Pierre. „Memoire collective”. W Faire d'histoire, red. Jacques Le Goff, Paris: Gallimard, 1974.

Skibiński, Franciszek. „Architekci, budowniczowie, kamieniarze i rzeźbiarze obcego pochodzenia w Gdańsku 1550-1630. Szkic z dziejów migracji artystycznej”. Biuletyn Historii Sztuki 77, nr 1 (2015): 5-35.

Skibiński, Franciszek. „Rzeźba kamienna w Toruniu ok. 1580-1650. Pomiędzy produkcją miejscową a importem z czołowych ośrodków rzeźbiarskich Rzeczypospolitej”. W Stare i nowe dziedzictwo Torunia, red. Juliusz Raczkowski, 206-224. Toruń: Wydział Sztuk Pięknych UMK, 2013.

Skibiński, Franciszek. Willem van den Blocke. Niderlandzki rzeźbiarz na Bałtykiem w XVI i na początku XVII wieku. Toruń: TNT, 2015.

Skibiński, Szczęsny. „Architektura kościołów średniowiecznego Poznania”. W Civitas Posnaniensis. Studia z dziejów średniowiecznego Poznania, red. Zofia Kurnatowska i Tomasz Jurek, 245-262. Poznań: Wydawnictwo PTPN, 2005.

Skibiński, Szczęsny. „Gotycka architektura kościoła farnego pod wezwaniem Marii Magdaleny we Wrocławiu”. W Początki i rozwój Starego Miasta w Poznaniu do XV wieku $w$ świetle nowych badań archeologicznych i urbanistyczno-architektonicznych, red. Włodzimierz Błaszczyk, 421-437. Poznań: Muzeum Archeologiczne, 1977.

Smulikowska, Ewa. Prospekty organowe $w$ dawnej Polsce. Wrocław-Warszawa-Kraków: Ossolineum, 1989.

Triumph der Phantasie. Barocke Modelle von Hilderbrandt bis Mollinarolo, red. Michael Krapf. Wien: Böhlau, 1998.

Warkoczewska, Magdalena. „Widoki kolegiaty farnej pw. św. Marii Magdaleny”. Kronika Miasta Poznania 3 (2003): 145-159.

Wicherkiewiczowa, Marja. Rynek poznański i jego patrycjat, wyd. 2. Poznań: Wydawnictwo Miejskie, 1998.

Wiesiołowski, Jacek. „Kolegiata św. Marii Magdaleny w świetle najstarszej wizytacji”. Kronika Miasta Poznania 3 (2003): 120-144.

Wiesiołowski, Jacek, i Rafał Wójcik. „Napisy nagrobne ze starej fary w Monumenta Sarmatarum Szymona Starowolskiego”. Kronika Miasta Poznania 3 (2003): 103-119. Wiliński, Stanisław. „Regestr czeladników i mistrzów cechu muratorów w Poznaniu z lat 1618-1679”. Przegląd Zachodni 9, nr 9-10 (1953): 211-235.

Władze miasta Poznania. T. 1, 1253-1793, red. Jacek Wiesiołowski i Zofia Wojciechowska. Poznań: Wydawnictwo Miejskie, 2003. 